\title{
Stunting pada Remaja Kawasan Buruh Industri dan Nelayan di Kota Surabaya
}

\author{
Stunting on Teenager in Industrial Labor and Coastal Area in Surabaya \\ City
}

\author{
Luluk Oktavia \\ Departemen Antropologi, Fakultas Ilmu Sosial dan Ilmu Politik, Universitas Airlangga \\ Alamat: Jalan Dharmawangsa Dalam Selatan, Surabaya, Indonesia 60286 \\ Email: luluk.oktavia-2016@fisip.unair.ac.id
}

\begin{abstract}
Abstrak
Penelitian ini dilakukan untuk mengetahui perbedaan kejadian stunting (kondisi pada anak yang memiliki tinggi badan kurang jika dibandingkan dengan umurnya) pada remaja yang tinggal pada lingkungan kawasan industri dan nelayan di Kota Surabaya. Metode penelitian ini adalah kuantitatif, dengan jumlah sampel sebanyak 145 responden. Uji statistik yang digunakan adalah chi square. Hasil penelitian menunjukkan bahwa 1) ada perbedaan status gizi TB/U remaja di kawasan buruh industri dan nelayan. Kejadian stunting lebih banyak terjadi di kawasan nelayan. Tingginya jumlah remaja stunting di kawasan nelayan tidak lepas dari jumlah saudara remaja yang tinggal di kawasan ini. 2) Ada perbedaan status sosial ekonomi pada remaja kawasan buruh industri dan nelayan. Kawasan buruh industri mayoritas berstatus sosial ekonomi atas, sedangkan kawasan nelayan berstatus sosial ekonomi bawah. 3) Status gizi IMT/U tidak menunjukkan adanya perbedaan pada remaja di kedua kawasan. Hal ini menggambarkan bahwa kebutuhan nutrisi remaja masih dapat terpenuhi, karena bertempat tinggal di Kota Surabaya mendukung adanya berbagai pasokan pangan yang mudah diperoleh. 4) Ada perbedaan kejadian stunting pada remaja laki-laki dan perempuan. Hal ini bisa disebabkan kebutuhan gizi ibu yang kurang selama kehamilan bisa berdampak rusaknya sel telur pada janin perempuan, dan sistem sosial yang masih menganut patriarki mengindikasikan anak laki-laki memiliki kesempatan lebih baik dalam pemenuhan kebutuhan gizi.
\end{abstract}

Kata kunci: status gizi TB/U dan IMT/U; stunting; lingkungan kawasan buruh industri; lingkungan kawasan nelayan

\begin{abstract}
The object of the research identifies the differences of stunting (when a child has a low height for their age) in teenagers living in both areas. The research employs a quantitative method with a total sample of 145 respondents. Chi-square is the statistical test in this research. The results show that 1) calculation nutritional status height-for-age of the teenager in industrial labor and coastal areas shows any difference. Stunting cases are more frequent in the coastal area. The considerable number of stunted teenagers in the coastal area is inseparable from the number of siblings who live there. 2) The socioeconomic status of the teenager in industrial labor and coastal areas shows any difference. The majority of industrial labor-areas has the upper socioeconomic status, while the coastal areas consider having lower socioeconomic status. 3) The nutritional status of BMI-for-age does not show any difference among teenagers in those areas. The condition portrays that a teenager's nutritional needs are fulfilled because living in Surabaya supports an obtainable variety of food supplies. 4) Stunting between boys and girls shows any difference. It can be due to the low maternal nutrition during pregnancy has an impact on the destruction of ovum, and the social system still adheres to patriarchy indicates a better chance for boys to fulfilling their nutritional needs.
\end{abstract}

Keywords: height-for-age and BMI-for-age nutritional status; stunting; industrial labor-areas; coastal area

Biokultur, 2020, 9 (1): 1-14. DOI: http://dx.doi.org/10.20473/bk.v9i1.21723.

Article History:

Received August 31, 2020; Accepted September 2, 2020; Published Online September 232020

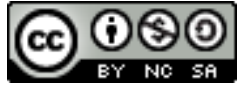




\section{Pendahuluan}

Stunting adalah suatu kondisi pada anak yang memiliki panjang atau tinggi badan kurang jika dibandingkan dengan umurnya (Trihono, Atmarita, Tjandrarini, Irawati, Utami, Tejayanti \& Nurlinawati 2015; TNP2K 2017; dan Pusdatin Kemkes RI 2018). Kondisi ini diukur dengan tinggi badan menurut umur (TB/U) atau panjang badan menurut umur $(\mathrm{PB} / \mathrm{U})$ dengan $z$-score $<-2$ Standar Deviasi yang dibandingkan dengan pertumbuhan anak dari WHO (Pusdatin Kemkes RI 2018). Anak stunting termasuk masalah gizi kronik yang disebabkan oleh banyak faktor seperti kondisi sosial ekonomi, sanitasi, gizi ibu saat hamil, sakit yang dialami ketika bayi, dan kurangnya asupan gizi ketika bayi. Pusat Data dan Informasi Kementerian Kesehatan RI (2018) mengungkapkan bahwa balita stunting di masa yang akan datang akan mengalami kesulitan dalam mencapai perkembangan fisik dan kognitif yang optimal.

Kejadian stunting akan terus berlanjut dari usia masa balita sampai usia remaja, jika tidak ada perbaikan gizi yang baik. Data dari Kementerian Kesehatan RI (2018) menyebutkan stunting pada remaja umur 16-18 tahun di Indonesia sebesar 37\% pada tahun 2017. Kasus remaja stunting di Jawa Timur sendiri mencapai 37,1\%. Di Kota Surabaya, prevalensi stunting tahun 2015 adalah 19,3\%, kemudian naik menjadi 28,57\% (2018) atau memiliki selisih 9,27\%. Fakta itu tentu menjadi permasalahan bagi masyarakat Surabaya. Sebagai ibu kota Jawa Timur, Surabaya merupakan pusat dari seluruh kegiatan sosial dan ekonomi warga dalam dan luar Jawa Timur. Heterogenitas dan banyaknya orang menggantungkan hidup di Ibu Kota Jawa Timur karena didukung oleh berbagai macam fasilitas dan mobilitas yang mudah, Surabaya masih memiliki permasalahan gizi yang tidak dapat dihindarkan, seperti stunting (Damayanti, Muniroh \& Farapti 2016).

Kawasan dengan pekerjaan yang mayoritas menghasilkan pendapatan per bulan tergolong rendah termasuk salah satu faktor dari status sosial ekonomi yang menjadikan Surabaya sebagai daerah yang masih terdapat kasus stunting (Damayanti, Muniroh \& Farapti 2016; Ni'mah \& Nadhiroh 2015; dan Permatasari \& Surmarmi 2018). Berdasarkan data dari Dinas Kesehatan Kota Surabaya pada tahun 2018, Kecamatan Sukomanunggal memiliki balita stunting sebanyak 390 anak atau sekitar 5,9\%. Kawasan ini merupakan daerah kawasan buruh industri yang terletak di wilayah Surabaya Timur. Kecamatan Bulak dan Kecamatan Kenjeran sebagai kawasan nelayan yang terletak di pesisir utara Kota Surabaya juga terdapat kasus kejadian stunting masing-masing sebesar $11,9 \%$ (337 anak) dan 17,7\% (2053 anak).

Kondisi lingkungan yang berbeda antara kawasan buruh industri dan nelayan bisa memberikan pengaruh terhadap kehidupan sosial, ekonomi, dan budaya pada kedua populasi (Pradani, Rahayu \& Putri 2017; Budiman \& Anshariah 2018; dan Setyorini 2013). Secara tidak langsung, bisa berdampak pada status sosial ekonomi keluarga di kawasan buruh industri maupun nelayan. Dalam penelitian Ngaisyah (2015), status sosial ekonomi sangat dipengaruhi oleh tingkat pendapatan keluarga, apabila akses pangan di tingkat rumah tangga terganggu, terutama akibat kemiskinan, maka penyakit kurang gizi (malnutrisi) seperti stunting pasti akan muncul. 
Sejak abad 18 sampai sekarang, kehidupan sosial ekonomi masyarakat pesisir di Indonesia mengalami fluktuasi karena skala usaha penangkapan ikan dan jumlah nelayan yang kadang meningkat dan menurun (Andriati 2018). Fluktuasi juga terjadi karena faktor gangguan alam, sehingga berpengaruh pada pendapatan nelayan yang tidak pasti. Sebagai contoh, penyebab budaya kemiskinan nelayan di Mangunharjo Semarang yang ditulis oleh Setyorini (2013) adalah kondisi alam di perairan semakin memprihatinkan karena fenomena global warming, perubahan alam yang tidak pasti, abrasi pantai, dan peningkatan pencemaran sehingga mengakibatkan hasil tangkapan menurun dan daerah penangkapan yang semakin jauh. Penelitian yang dilakukan oleh Pradani, Rahayu \& Putri (2017) kawasan industri di permukiman Cemani Kabupaten Sukoharjo memiliki dampak yang terbilang tidak menguntungkan. Karena menjadikan adanya polusi akibat limbah yang bermuara ke sungai di dekat industri, kawasan banjir akibat banyak berdiri bangunan sebagai permukiman pekerja industri maupun orang yang bermigrasi untuk mencari keberuntungan di kawasan industri, sehingga di Cemani juga timbul permukiman kumuh di sekitar sungai yang pada dasarnya ilegal untuk permukiman. Penelitian yang dilakukan oleh Ulfani, Martianto \& Baliwati (2011) memberikan jawaban bahwa perilaku higiene berpengaruh terhadap stunted.

Pada paparan penelitian di atas, bisa dilihat bahwa kawasan nelayan dan kawasan buruh industri masih memiliki permasalahan pelik terkait kondisi lingkungan dan potensi buruk yang timbul dalam pemenuhan gizi masyarakatnya. Oleh karena itu, peneliti tertarik untuk mencari tahu apakah kondisi lingkungan yang berbeda antara kawasan buruh industri dan nelayan akan menimbulkan perbedaan pula dalam memenuhi kebutuhan gizi, khususnya gizi kurang yang mengakibatkan stunting pada remaja.

\section{Metode}

Metode penelitian yang digunakan adalah statistik deskriptif dengan uji statistik chi square. Pengambilan sampel dilakukan dengan menggunakan teknik purposive sampling. Sampel yang dijadikan dalam penelitian ini adalah remaja laki-laki dan remaja perempuan berumur 15 hingga 18 tahun, yang sedang duduk di bangku sekolah menengah atas atau sederajat di kawasan buruh industri dan nelayan Kota Surabaya. Remaja pada kawasan buruh industri mengambil lokasi di SMK Pawiyatan, SMK Sejahtera, dan SMA Sejahtera yang merupakan satu kelurahan yakni Kelurahan Simomulyo Kecamatan Sukomanunggal. Pada kawasan nelayan, remaja yang dijadikan sampel penelitian berasal dari SMAN 19 Surabaya dan SMK Putra Airlangga Kecamatan Kenjeran, serta SMAN 3

Surabaya dan SMK Tri Guna Bhakti Kecamatan Bulak. Sampel yang diambil dalam penelitian ini sebesar 145 responden, 67 responden dari kawasan buruh industri dan 78 dari kawasan nelayan. Variabel independen atau yang mempengaruhi dalam penelitian ini adalah kawasan buruh industri dan kawasan nelayan, jenis kelamin, dan status sosial ekonomi. Variabel dependen atau yang dipengaruhi dalam penelitian ini yaitu variabel TB/U dan IMT/U atau indikator status gizi remaja menurut WHO (2007), status sosial ekonomi, dan kejadian stunting pada remaja kawasan buruh industri dan nelayan di Kota Surabaya. 


\section{Hasil Penelitian dan Pembahasan}

Hasil penghitungan chi square untuk mengetahui perbedaan status gizi TB/U remaja lakilaki dan perempuan pada kawasan buruh industri dan nelayan terlihat pada Tabel $1 \mathrm{di}$ bawah ini.

\section{Tabel 1 Perbedaan Status Gizi TB/U Remaja Laki-Laki dan Perempuan pada Kedua Sampel Populasi}

\begin{tabular}{|c|c|c|c|c|c|c|c|c|c|}
\hline \multirow{3}{*}{ Populasi } & \multirow{3}{*}{\multicolumn{2}{|c|}{ Variabel }} & \multicolumn{4}{|c|}{$\mathrm{TB} / \mathrm{U}$} & \multirow{2}{*}{\multicolumn{2}{|c|}{ Total }} & \multirow{3}{*}{$\begin{array}{l}\text { Uji Chi } \\
\text { Square }\end{array}$} \\
\hline & & & \multicolumn{2}{|c|}{$<-2 \mathrm{SD}$} & \multicolumn{2}{|c|}{$\geq-2,0 \mathrm{SD}$} & & & \\
\hline & & & $\mathrm{N}$ & $\%$ & $\mathrm{n}$ & $\%$ & $\mathrm{~N}$ & $\%$ & \\
\hline \multirow{3}{*}{$\begin{array}{l}\text { Kawasan } \\
\text { Buruh } \\
\text { Industri }\end{array}$} & Jenis & $L$ & 4 & $13 \%$ & 28 & $88 \%$ & 32 & $100 \%$ & \multirow{3}{*}{0,037} \\
\hline & Kelamin & $P$ & 12 & $34 \%$ & 23 & $66 \%$ & 35 & $100 \%$ & \\
\hline & Total & & 16 & $24 \%$ & 51 & $76 \%$ & 67 & $100 \%$ & \\
\hline \multirow{3}{*}{$\begin{array}{l}\text { Kawasan } \\
\text { Nelayan }\end{array}$} & Jenis & $\mathrm{L}$ & 10 & $27 \%$ & 27 & $73 \%$ & 37 & $100 \%$ & \multirow{3}{*}{0,049} \\
\hline & Kelamin & $P$ & 20 & $49 \%$ & 21 & $51 \%$ & 41 & $100 \%$ & \\
\hline & Total & & 30 & $38 \%$ & 48 & $62 \%$ & 78 & $100 \%$ & \\
\hline
\end{tabular}

Sumber: Data primer, diolah.

Tabel 1 menunjukkan adanya perbedaan yang signifikan status gizi TB/U remaja di kawasan buruh industri dan kawasan nelayan. Pada kawasan buruh industri diperoleh nilai sebesar 0,037 $<0,05$ dan pada kawasan nelayan sebesar $0,049<0,05$, sehingga $\mathrm{H} 0$ ditolak. Pada kawasan buruh industri, total remaja stunting sebesar 24\%. Jumlah tersebut lebih kecil daripada jumlah remaja stunting di kawasan nelayan yang mencapai $38 \%$.

Uji perbedaan status gizi IMT/U pada remaja laki-laki dan perempuan yang tinggal di kawasan buruh industri dan nelayan dapat diketahui pada Tabel 2.

Tabel 2 Perbedaan Status Gizi IMT/U Remaja Laki-Laki dan Perempuan pada Kedua Sampel Populasi

\begin{tabular}{|c|c|c|c|c|c|c|c|c|c|c|c|}
\hline \multirow{3}{*}{ Populasi } & \multirow{3}{*}{ Variabel } & & \multicolumn{6}{|c|}{ IMT/U } & \multirow{2}{*}{\multicolumn{2}{|c|}{ Total }} & \multirow{3}{*}{$\begin{array}{l}\text { Uji Ch } \\
\text { Square }\end{array}$} \\
\hline & & & \multicolumn{2}{|c|}{$<-2$ SD } & \multicolumn{2}{|c|}{$\begin{array}{l}\geq-2,0 \mathrm{~s} / \mathrm{d} \\
\leq 1,0 \mathrm{SD}\end{array}$} & \multicolumn{2}{|c|}{$>1,0 \mathrm{SD}$} & & & \\
\hline & & & $n$ & $\%$ & $\mathrm{~N}$ & $\%$ & $\mathrm{n}$ & $\%$ & $\mathrm{~N}$ & $\%$ & \\
\hline \multirow{3}{*}{$\begin{array}{l}\text { Kawasan } \\
\text { Buruh } \\
\text { Industri }\end{array}$} & Jenis & $\mathrm{L}$ & 4 & $13 \%$ & 24 & $75 \%$ & 4 & $13 \%$ & 32 & $100 \%$ & \multirow{3}{*}{0,305} \\
\hline & Kelamin & $\mathrm{P}$ & 1 & $3 \%$ & 28 & $80 \%$ & 6 & $17 \%$ & 35 & $100 \%$ & \\
\hline & Total & & 5 & $7 \%$ & 52 & $78 \%$ & 10 & $15 \%$ & 67 & $100 \%$ & \\
\hline \multirow{3}{*}{$\begin{array}{l}\text { Kawasan } \\
\text { Nelayan }\end{array}$} & Jenis & $\mathrm{L}$ & 5 & $14 \%$ & 25 & $68 \%$ & 7 & $19 \%$ & 37 & $100 \%$ & \multirow{3}{*}{0,656} \\
\hline & Kelamin & $\mathrm{P}$ & 3 & $7 \%$ & 29 & $71 \%$ & 9 & $22 \%$ & 41 & $100 \%$ & \\
\hline & Total & & 8 & $10 \%$ & 54 & $69 \%$ & 16 & $21 \%$ & 78 & $100 \%$ & \\
\hline
\end{tabular}

Sumber: Data primer, diolah.

Tabel 2 dari perbedaan uji chi square, diperoleh nilai sebesar 0,305 $>0,05$ pada kawasan buruh industri dan 0,656 > 0,05 pada kawasan nelayan, sehingga H0 diterima. Artinya tidak ada perbedaan yang signifikan status gizi IMT/U pada remaja laki-laki dan perempuan di kedua sampel populasi. Nilai z-score $<-2$ SD adalah remaja yang tergolong 
kurus, $z$-score $\geq-2,0 \mathrm{~s} / \mathrm{d} \leq 1,0 \mathrm{SD}$ adalah remaja yang memiliki indeks massa tubuh normal, dan $z$-score $>1,0 \mathrm{SD}$ adalah remaja yang memiliki indek massa tubuh melebihi normal yaitu gemuk atau bahkan obesitas berdasarkan status gizi IMT/U.

Status gizi remaja yang dilihat dari indikator TB/U dan IMT/U di atas tidak bisa lepas dari status sosial ekonomi. Oleh karena itu, penelitian ini juga menguji ada tidaknya hubungan antara status sosial ekonomi dengan kejadian stunting yang tersaji dalam Tabel 3.

Tabel 3 Hubungan antara Status Sosial Ekonomi dengan Kejadian Stunting Remaja pada Kedua Sampel Populasi

\begin{tabular}{|c|c|c|c|c|c|c|c|}
\hline & & \multicolumn{4}{|c|}{ Kejadian Stunting } & \multirow{2}{*}{\multicolumn{2}{|c|}{ Total }} \\
\hline \multicolumn{2}{|c|}{ Variabel } & \multicolumn{2}{|c|}{ Stunting } & \multicolumn{2}{|c|}{ Tidak Stunting } & & \\
\hline & & $\mathrm{N}$ & $\%$ & $\mathrm{~N}$ & $\%$ & $\mathrm{~N}$ & $\%$ \\
\hline \multirow{3}{*}{$\begin{array}{l}\text { Status Sosial } \\
\text { Ekonomi }\end{array}$} & Bawah & 13 & $37 \%$ & 22 & $63 \%$ & 35 & $100 \%$ \\
\hline & Menengah & 29 & $35 \%$ & 54 & $65 \%$ & 83 & $100 \%$ \\
\hline & Atas & 4 & $15 \%$ & 23 & $85 \%$ & 27 & $100 \%$ \\
\hline \multicolumn{2}{|c|}{ Total } & 46 & $32 \%$ & 99 & $68 \%$ & 145 & $100 \%$ \\
\hline \multicolumn{2}{|c|}{ Uji Chi-Square } & \multicolumn{6}{|c|}{0,109} \\
\hline
\end{tabular}

Sumber: Data primer, diolah.

Tabel 3 menunjukkan data hasil uji hubungan chi square yang memperoleh nilai sebesar $0,109>0,05$, sehingga $\mathrm{H}_{0}$ diterima. Hal tersebut menunjukkan bahwa tidak ada hubungan yang signifikan antara status sosial ekonomi keluarga responden dengan kejadian stunting pada kedua sampel populasi. Hasil data yang diperoleh di lapangan, stunting lebih banyak terjadi pada remaja yang memiliki status sosial ekonomi bawah dengan persentase sebesar $37 \%$. Nilai tersebut terbilang lebih besar daripada remaja yang memiliki status sosial ekonomi menengah dengan persentase $35 \%$, dan remaja yang berstatus sosial ekonomi atas memiliki kasus stunting lebih kecil dengan persentase $15 \%$.

Kasus stunting lebih banyak terjadi pada remaja yang tergolong memiliki status sosial ekonomi bawah (Tabel 3), maka uji statistik dilanjutkan untuk mengetahui ada tidaknya perbedaan status sosial ekonomi remaja di kawasan buruh industri dan nelayan pada Tabel 4.

Tabel 4 Perbedaan Status Sosial Ekonomi Remaja pada Kedua Sampel Populasi

\begin{tabular}{|c|c|c|c|c|c|c|c|}
\hline & \multirow{3}{*}{ Variabel } & \multicolumn{4}{|c|}{ Populasi } & \multirow{2}{*}{\multicolumn{2}{|c|}{ Total }} \\
\hline & & \multicolumn{2}{|c|}{$\begin{array}{c}\text { Kawasan Buruh } \\
\text { Industri }\end{array}$} & \multicolumn{2}{|c|}{ Kawasan Nelayan } & & \\
\hline & & $\mathrm{n}$ & $\%$ & $n$ & $\%$ & $\mathrm{~N}$ & $\%$ \\
\hline Status & Bawah & 10 & $29 \%$ & 25 & $71 \%$ & 35 & $100 \%$ \\
\hline Sosial & Menengah & 37 & $45 \%$ & 46 & $55 \%$ & 83 & $100 \%$ \\
\hline \multirow[t]{2}{*}{ Ekonomi } & Atas & 20 & $74 \%$ & 7 & $26 \%$ & 27 & $100 \%$ \\
\hline & Total & 67 & $46 \%$ & 78 & $54 \%$ & 145 & $100 \%$ \\
\hline \multicolumn{2}{|c|}{ Uji Chi-Square } & \multicolumn{6}{|c|}{0,002} \\
\hline
\end{tabular}

Sumber: Data primer, diolah. 
Tabel 4 diketahui bahwa nilai dari uji chi square adalah $0,002<0,05$, artinya $\mathrm{H}_{0}$ ditolak. Hal tersebut bisa diterjemahkan bahwa ada perbedaan yang signifikan status sosial ekonomi pada kawasan buruh industri dan kawasan nelayan di Kota Surabaya. Pada sampel populasi kawasan buruh industri, status sosial ekonomi paling banyak adalah memiliki tingkat status sosial ekonomi atas sebesar $74 \%$, sedangkan pada kawasan nelayan paling banyak adalah memiliki status sosial ekonomi bawah sebesar $71 \%$.

Pada segi lingkungan, Tabel 1 menunjukkan bahwa kawasan nelayan lebih banyak terdapat kejadian stunting daripada di kawasan buruh industri. Untuk meninjau lebih dalam bila berdasarkan jenis kelamin, maka uji statistik juga dilakukan untuk melihat apakah ada perbedaan kejadian stunting pada remaja laki-laki dan perempuan yang tinggal di kedua kawasan seperti yang terlihat pada Tabel 5.

\section{Tabel 5 Perbedaan Kejadian Stunting pada Remaja Laki-Laki dan Perempuan di Kedua} Sampel Populasi

\begin{tabular}{|c|c|c|c|c|c|c|c|}
\hline \multirow{3}{*}{\multicolumn{2}{|c|}{ Variabel }} & \multicolumn{4}{|c|}{ Kejadian Stunting } & \multirow{2}{*}{\multicolumn{2}{|c|}{ Total }} \\
\hline & & \multicolumn{2}{|c|}{ Stunting } & \multicolumn{2}{|c|}{ Tidak Stunting } & & \\
\hline & & $\mathrm{N}$ & $\%$ & $\mathrm{n}$ & $\%$ & $\mathrm{~N}$ & $\%$ \\
\hline \multirow[t]{2}{*}{ Jenis Kelamin } & Laki-laki & 14 & $20 \%$ & 55 & $80 \%$ & 69 & $100 \%$ \\
\hline & Perempuan & 32 & $42 \%$ & 44 & $58 \%$ & 76 & $100 \%$ \\
\hline \multicolumn{2}{|c|}{ Total } & 46 & $32 \%$ & 99 & $68 \%$ & 145 & $100 \%$ \\
\hline \multicolumn{2}{|c|}{ Uji Chi-Square } & \multicolumn{4}{|c|}{0,005} & & \\
\hline
\end{tabular}

Sumber: Data primer, diolah.

Tabel 5 diperoleh nilai dari uji chi square sebesar 0,005 <0,05, dapat disimpulkan bahwa terdapat perbedaan yang signifikan kejadian stunting pada remaja laki-laki dan perempuan di kedua sampel populasi. Remaja stunting lebih banyak terjadi pada jenis kelamin perempuan daripada laki-laki.

Jumlah saudara kandung yang dijadikan sampel penelitian menjadi salah satu faktor penyebab banyaknya kasus stunting. Tabel 6 disajikan untuk melihat distribusi frekuensi jumlah saudara kandung remaja pada kedua sampel populasi.

Tabel 6 Distribusi Frekuensi Jumlah Saudara Kandung Remaja pada Kedua Sampel Populasi

\begin{tabular}{ccccc}
\hline \multirow{2}{*}{ Jumlah saudara } & \multicolumn{2}{c}{ Kawasan Buruh Industri } & \multicolumn{2}{c}{ Kawasan Nelayan } \\
\cline { 2 - 5 } & Jumlah & Persentase & Jumlah & Persentase \\
\hline 0 & 4 & $6 \%$ & 2 & $3 \%$ \\
1 & 15 & $22 \%$ & 11 & $14 \%$ \\
2 & 24 & $36 \%$ & 24 & $31 \%$ \\
3 & 18 & $27 \%$ & 21 & $27 \%$ \\
4 & 4 & $6 \%$ & 15 & $19 \%$ \\
5 & 2 & $3 \%$ & 3 & $4 \%$ \\
6 & 0 & $0 \%$ & 2 & $3 \%$ \\
\hline Total & 67 & $100 \%$ & 78 & $100 \%$ \\
\hline
\end{tabular}

Sumber: Data primer, diolah. 
Tabel 6 memperlihatkan bahwa baik pada kawasan buruh industri dan kawasan nelayan, responden paling banyak memiliki dua saudara, dengan persentase $36 \%$ pada kawasan buruh industri dan $31 \%$ pada kawasan nelayan. Remaja di kawasan buruh industri selain memiliki dua saudara paling banyak, juga mempunyai satu dan tiga saudara paling banyak selanjutnya. Pada kawasan nelayan, remaja paling banyak memiliki tiga dan empat saudara paling banyak berikutnya selain mempunyai dua saudara, dan ada yang sampai memiliki enam saudara dalam sebuah keluarga.

Status sosial ekonomi dapat dilihat pada beberapa faktor yang dijadikan indikator dalam penelitian ini. Untuk mengetahui distribusi frekuensi masing-masing faktor, dapat dilihat pada Tabel 7 di bawah.

Tabel 7 Distribusi Frekuensi Indikator Status Sosial Ekonomi Remaja pada Kedua Sampel Populasi

\begin{tabular}{|c|c|c|c|c|}
\hline \multirow{2}{*}{ Sosial Ekonomi Keluarga } & \multicolumn{2}{|c|}{ Kawasan Buruh Industri } & \multicolumn{2}{|c|}{ Kawasan Nelayan } \\
\hline & Jumlah & Persentase & Jumlah & Persentase \\
\hline $\begin{array}{l}\text { Pekerjaan Ayah } \\
\text { Kategori } 1 \text { (tidak bekerja, nelayan, } \\
\text { pekerja kasar, tenaga kebersihan, } \\
\text { jasa, dan tenaqa YBDI) }\end{array}$ & 29 & $43 \%$ & 67 & $86 \%$ \\
\hline $\begin{array}{l}\text { Kategori } 2 \text { (buruh industri, pegawai } \\
\text { swasta, dan PNS/TNI/POLRI) }\end{array}$ & 38 & $57 \%$ & 11 & $14 \%$ \\
\hline Total & 67 & $100 \%$ & 78 & $100 \%$ \\
\hline \multicolumn{5}{|l|}{ Pekerjaan Ibu } \\
\hline Kategori 1 (tidak bekerja) & 39 & $58 \%$ & 45 & $58 \%$ \\
\hline $\begin{array}{l}\text { Kategori } 2 \text { (nelayan, tenaga } \\
\text { kebersihan, jasa, dan tenaga YBDI) }\end{array}$ & 11 & $16 \%$ & 26 & $33 \%$ \\
\hline $\begin{array}{l}\text { Kategori } 3 \text { (buruh industri, pegawaí } \\
\text { swasta, dan PNS) }\end{array}$ & 17 & $25 \%$ & 7 & $9 \%$ \\
\hline Total & 67 & $100 \%$ & 78 & $100 \%$ \\
\hline \multicolumn{5}{|l|}{ Pendidikan Terakhir Ayah } \\
\hline Rendah (tidak sekolah, SD, dan SMP) & 23 & $34 \%$ & 38 & $49 \%$ \\
\hline Tinggi (SMA dan PT/Akademi) & 44 & $66 \%$ & 40 & $51 \%$ \\
\hline Total & 67 & $100 \%$ & 78 & $100 \%$ \\
\hline \multicolumn{5}{|l|}{ Pendidikan Terakhir Ibu } \\
\hline Rendah (tidak sekolah, SD, dan SMP) & 24 & $36 \%$ & 43 & $55 \%$ \\
\hline Tinggi (SMA dan PT/Akademi) & 43 & $64 \%$ & 35 & $45 \%$ \\
\hline Total & 67 & $100 \%$ & 78 & $100 \%$ \\
\hline \multicolumn{5}{|l|}{ Penghasilan Keluarga Per Bulan } \\
\hline Rendah (kuintil 1 dan 2) & 8 & $12 \%$ & 16 & $21 \%$ \\
\hline Sedang (kuintil 3) & 19 & $28 \%$ & 37 & $47 \%$ \\
\hline Tinggi (kuintil 4 dan 5) & 40 & $60 \%$ & 25 & $32 \%$ \\
\hline Total & 67 & $100 \%$ & 78 & $100 \%$ \\
\hline \multicolumn{5}{|l|}{ Pengeluaran Kebutuhan Per Hari } \\
\hline Rendah (kuintil 1 dan 2) & 24 & $36 \%$ & 29 & $37 \%$ \\
\hline Sedang (kuintil 3) & 22 & $33 \%$ & 28 & $36 \%$ \\
\hline Tingqi (kuintil 4 dan 5) & 21 & $31 \%$ & 21 & $27 \%$ \\
\hline Total & 67 & $100 \%$ & 78 & $100 \%$ \\
\hline
\end{tabular}

Sumber: Data primer, diolah. 
Tabel 7 pada pekerjaan ayah diperoleh data sebesar $43 \%$ pada kategori pertama dan sebesar 57\% pada kategori ke dua untuk kawasan buruh industri. Pada kawasan nelayan untuk kategori pertama diperoleh sampel sebesar 86\%, dan kategori ke dua diperoleh sampel sebesar 14\%. Pada pekerjaan ibu di kawasan buruh industri, sebesar 58\% ibu responden termasuk kategori pertama, $16 \%$ termasuk kategori ke dua, dan $25 \%$ termasuk kategori ke tiga. Pada sampel kawasan nelayan, diperoleh sampel sebanyak 58\% untuk kategori pertama, 33\% untuk kategori ke dua, dan 9\% untuk kategori ke tiga. Pada pendidikan terakhir ayah baik di kawasan buruh industri maupun nelayan tergolong memiliki pendidikan tinggi. Pada pendidikan terakhir ibu di kawasan buruh industri tergolong tinggi, sedangkan di kawasan nelayan tergolong rendah. Penghasilan keluarga per bulan kuintil 1 dalam penelitian ini adalah < Rp 500.000, kuintil 2 adalah Rp 500.000 - Rp 1.499.999, kuintil 3 adalah Rp 1.500.000 - Rp 2.999.999, kuintil 4 adalah Rp 3.000.000 - Rp 4.499.999, dan kuintil 5 adalah Rp 4.500.000 - Rp 8.000.000. Pada kawasan buruh industri, penghasilan keluarga mayoritas memiliki penghasilan tinggi. Sementara itu, di kawasan nelayan tergolong memiliki penghasilan yang lebih rendah dari kawasan buruh industri. Pengeluaran kebutuhan per hari dalam penelitian kuintil 1 adalah $<$ Rp 50.000, kuintil 2 adalah Rp 50.000 - Rp 99.999, kuintil 3 adalah Rp 100.000 - Rp 149.999, kuintil 4 adalah Rp 150.000 - Rp 199.999, dan kuintil 5 adalah Rp 200.000 - Rp 300.000. Baik pada kawasan buruh industri atau di kawasan nelayan sama-sama memiliki pengeluaran kebutuhan per hari yang tergolong rendah.

Status gizi remaja pada rentang usia 15-18 tahun dapat dilihat melalui nilai $z$-score indikator status gizi TB/U dan IMT/U yang merujuk pada standar baku status gizi dari WHO (2007). Berdasarkan uji statistik chi square, Tabel 1 hasil dari penelitian ini menunjukkan adanya perbedaan yang signifikan status gizi TB/U antara remaja laki-laki dan perempuan di kawasan buruh industri $(0,037<0,05)$. Begitu pula di kawasan nelayan menunjukkan adanya perbedaan yang signifikan status gizi TB/U antara remaja laki-laki dan perempuan $(0,049<0,05)$. Z-score < -2 SD atau stunting remaja di kawasan nelayan memperlihatkan hasil yang lebih besar daripada remaja di kawasan buruh industri. Remaja laki-laki yang tergolong stunting di kawasan buruh industri sebesar 13\%, sebuah nilai yang terbilang kecil dibandingkan jumlah stunting remaja laki-laki di kawasan nelayan yang mencapai $27 \%$. Remaja perempuan yang tergolong stunting di kawasan buruh industri juga memiliki jumlah yang lebih kecil yaitu $34 \%$, dibandingkan remaja perempuan di kawasan nelayan yang mencapai $49 \%$. Jika dijumlahkan, maka stunting di kawasan buruh industri adalah 24\% dan di kawasan nelayan 38\%, sehingga bisa dikatakan bahwa stunting lebih banyak terjadi pada remaja kawasan nelayan daripada remaja kawasan buruh industri.

Bertempat tinggal di kawasan nelayan yang sepantasnya lebih mudah memperoleh akses pangan khususnya dalam mengonsumsi ikan, rupanya tidak menjadikan remaja yang tinggal di dalamnya dapat memenuhi kebutuhan gizi untuk mencapai pertumbuhan maksimalnya. Protein yang terkandung dalam ikan mengandung banyak manfaat, salah satunya dalam proses pertumbuhan. Protein dapat meningkatkan insulin-like growth factor 1 (IGF-1) yang mempengaruhi perkembangan tulang melalui peningkatan pembentukan tulang (Bonjour 2005; Dawson-Hughes 2003 dalam Katzenberg \& Saunders 2008: 394). Tingginya jumlah remaja stunting di kawasan nelayan ini tidak lepas dari jumlah saudara remaja yang tinggal di kawasan ini. Pada Tabel 6 memperlihatkan bahwa mayoritas jumlah saudara remaja di kawasan nelayan memiliki 
dua saudara dengan persentase sebesar $31 \%$, sebesar $27 \%$ memiliki tiga saudara, $19 \%$ memiliki empat saudara, bahkan ada yang memiliki lima saudara sebesar $4 \%$, dan 3\% memiliki enam saudara. Meskipun ada juga yang tidak memiliki saudara sebesar 3\% dan hanya mempunyai satu saudara sebesar 14\%. Banyaknya jumlah saudara dalam sebuah keluarga tentu akan mempengaruhi distribusi pangan setiap anggota keluarga, terutama keluarga yang berstatus sosial ekonomi bawah akan lebih mudah memenuhi kebutuhan pangannya jika yang harus diberi makan jumlahnya sedikit. Seperti dalam penelitian Ramadhan, Simanungkalit \& Wahyuningtyas (2019), bahwa jumlah anggota keluarga memiliki hubungan dengan kejadian stunting. Banyaknya jumlah saudara juga akan mempengaruhi beban ekonomi suatu keluarga seperti untuk memenuhi kebutuhan sandang, pendidikan, dan sebagainya yang harus dipenuhi setiap individu, tidak terkecuali kebutuhan gizi pada setiap anggota keluarga. Apabila pemenuhan nutrisi ini tidak adekuat, maka akan menyebabkan terjadinya permasalah gizi yang berpotensi menjadikan anak stunting.

Berdasarkan status gizi indikator TB/U menunjukkan remaja stunting lebih banyak di kawasan nelayan daripada di kawasan buruh industri, namun ini tidak bisa langsung dikatakan sebagai stunting. Pertumbuhan remaja bisa disebabkan oleh beberapa faktor yaitu genetik, hormon pertumbuhan, dan lingkungan yang beroperasi sedemikian rupa selama periode pertumbuhan (Cameron 2002). Bila berdasarkan faktor genetik, penelitian yang dilakukan oleh Nasikhah \& Margawati (2012) membuktikan bahwa tinggi badan orangtua ada hubungannya dengan pertumbuhan fisik anak. Hormon pertumbuhan juga memiliki peran dalam pertumbuhan remaja, baik tidaknya lingkungan akan mempengaruhi pelepasan hormon yang berpengaruh pada tinggi badan seseorang selama proses pertumbuhan (Cameron 2002).

Hubungan antara kualitas lingkungan dan status pertumbuhan memiliki pengaruh jika lingkungan sosial dan ekonomi memberikan hambatan besar dalam pembangunan (Johnston 2002). Status pertumbuhan ini tidak bisa lepas dari kejadian stunting yang bisa disebabkan oleh status sosial ekonomi. Pada Tabel 3 hasil uji statistik chi square menunjukkan bahwa tidak ada hubungan yang signifikan antara status sosial ekonomi dengan kejadian stunting $(0,109>0,05)$. Meskipun demikian, stunting lebih banyak terjadi pada remaja yang memiliki status sosial ekonomi bawah dengan persentase sebesar $37 \%$, dan persentase stunting terendah terjadi pada remaja yang memiliki status sosial ekonomi atas dengan nilai sebesar $15 \%$. Adanya kasus stunting yang lebih banyak terjadi pada remaja yang tergolong berstatus sosial ekonomi bawah, maka uji statistik dilanjutkan untuk mengetahui ada tidaknya perbedaan status sosial ekonomi remaja pada kawasan buruh industri dan nelayan.

Pada Tabel 4 hasil uji statistik chi square diperoleh nilai $0,002<0,05$, menunjukkan bahwa terdapat perbedaan yang signifikan mengenai status sosial ekonomi remaja di kawasan buruh industri dan kawasan nelayan. Status sosial ekonomi remaja pada populasi kawasan buruh industri paling banyak adalah memiliki status sosial ekonomi atas dengan persentase $74 \%$. Sementara itu, status sosial ekonomi remaja pada populasi kawasan nelayan paling banyak memiliki status sosial ekonomi bawah dengan persentase $71 \%$. Kawasan nelayan yang mayoritas memiliki status sosial ekonomi bawah ini dikuatkan oleh pernyataan Johnston (2002), bahwa orang yang termarjinalkan secara sosial dan ekonomi sangat mempengaruhi status pertumbuhan anak, tidak terkecuali pertumbuhan 
anak yang dapat menyebabkan resiko stunting.

Perbedaan status sosial ekonomi ini bisa dilihat pada beberapa faktor yang dijadikan indikator pengukuran dalam penelitian ini. Tabel 7 menunjukan bahwa pekerjaan ayah pada kawasan buruh industri lebih banyak bekerja pada kategori ke dua sebesar $57 \%$. Sementara itu, pada kawasan nelayan, ayah lebih banyak bekerja pada kategori pertama sebanyak $86 \%$. Pembagian kategori pekerjaan ayah ini didasarkan pada rata-rata penghasilan yang diperoleh dari profesi yang dijalankan, sehingga dapat berpotensi mempengaruhi penghasilan keluarga untuk memberikan nutrisi pada anak. Pekerjaan ayah di kawasan nelayan lebih banyak yang bekerja pada kategori pertama, yang berhubungan dengan banyaknya remaja stunting di daerah ini. Pekerjaan yang menghasilkan gaji atau upah rendah dapat mempengaruhi ekonomi keluarga dalam mencukupi kebutuhan nutrisi, terutama gizi ibu ketika hamil dan bayi selama 1000 hari pertama kehidupan. Jika dalam masa itu nutrisi ibu dan bayi tidak terpenuhi akan mengakibatkan anak menjadi stunting (TNP2K 2017).

Tabel 7 pada pekerjaan ibu memperlihatkan bahwa baik pada kawasan buruh industri dan kawasan nelayan, pekerjaan ibu paling banyak adalah sebagai ibu rumah tangga atau tidak bekerja. Mayoritas ibu yang tidak bekerja baik di kawasan buruh industri dan kawasan nelayan dalam penelitian ini berhubungan dengan pendidikan terakhir ibu dan kondisi ekonomi keluarga. Sebagai masyarakat kota metropolitan, ibu yang bekerja turut menambah pendapatan keluarga. Seperti penelitian yang dilakukan oleh Sulastri (2012) di Kota Padang, bahwa anak stunting lebih banyak terjadi pada ibu yang tidak bekerja. Banyaknya anak stunting pada ibu yang tidak bekerja disebabkan karena tingkat ekonomi yang rata-rata berada pada tingkat ekonomi rendah, juga rendahnya pengetahuan ibu tentang gizi.

Pendidikan terakhir ayah di kedua kawasan sama-sama tergolong memiliki riwayat pendidikan yang tinggi, yaitu lulusan SMA dan PT/Akademi (Tabel 7). Walaupun pendidikan terakhir ayah di kedua kawasan memiliki persamaan, namun karena tinggal di daearah yang memiliki karakter kawasan buruh industri dan kawasan nelayan menjadikan pekerjaan ayah yang dijalankan ada perbedaan, sehingga dapat mempengaruhi status ekonomi keluarga.

Pendidikan terakhir ibu di kawasan buruh industri cenderung lebih tinggi dibandingan yang ada di kawasan nelayan, dengan persentase $64 \%$ berpendidikan tinggi di kawasan buruh industri dan 55\% berpendidikan rendah di kawasan nelayan (Tabel 7). Masih rendahnya tingkat pendidikan ibu di kawasan nelayan berkorelasi dengan banyaknya stunting di daerah ini. Sesuai dengan penelitian Sulastri (2012), bahwa anak stunting lebih banyak terjadi pada ibu yang memiliki pendidikan rendah. Tingkat pendidikan ibu akan mempengaruhi keadaan gizi anak. Ibu yang berpendidikan tinggi akan memiliki kesempatan yang lebih jelas dalam menyerap informasi bila dibandingkan dengan ibu yang kurang berpendidikan. Pengetahuan ibu yang kurang terutama tentang pemenuhan nutrisi yang seharusnya dikonsumsi selama hamil akan mempengaruhi kesehatan janin dalam kandungannya. Ketika janin kekurangan gizi, maka ukuran hati, jaringan otot, dan organ-organ lainnya akan berkurang untuk mempertahankan nutrisi yang cukup untuk otak janin yang berkembang pesat (Jurmain, Kilgore \& Trevathan 2009). Pengetahuan ibu yang kurang terkait pola asuh dalam memberikan asupan nutrisi pada bayi selama 
1000 HPK juga akan menyebabkan permasahan gizi pada anak, dan bisa mengalami keterlambatan pertumbuhan yang dapat berujung stunting.

Penghasilan keluarga per bulan pada Tabel 7 memperlihatkan bahwa kawasan buruh industri mayoritas memiliki penghasilan per bulan yang tergolong tinggi dengan persentase sebesar $60 \%$, sedangkan kawasan nelayan mayoritas berpenghasilan sedang dengan persentase sebesar $47 \%$. Penghasilan yang tergolong rendah juga menunjukkan lebih banyak terjadi pada kawasan nelayan dengan persentase sebesar $21 \%$, sedangkan pada kawsan buruh industri hanya sebesar $12 \%$. Adanya perbedaan penghasilan pada kedua kawasan tidak lepas dari mayoritas profesi yang dijalankan oleh orangtua yang ada di kawasan buruh industri dan kawasan nelayan. Banyaknya stunting di kawasan nelayan tidak lepas dari penghasilan keluarga yang tergolong sedang dan rendah di daerah ini. Penghasilan ini diindikasikan karena jenis pekerjaan orangtua pada kawasan nelayan yang cenderung fluktuatif, utamanya kategori pertama dengan jenis pekerjaan sebagai nelayan. Profesi sebagai nelayan cenderung memiliki penghasilan yang fluktuatif karena ketidakpastian hasil tangkapan yang diperoleh ketika melaut (Andriati 2018). Berbeda halnya dengan kawasan buruh industri yang lebih banyak memiliki jenis pekerjaan pada kategori ke dua, utamanya profesi sebagai buruh industri. Pekerjaan ini cenderung memiliki pendapatan yang pasti karena gaji yang didapatkan setiap bulan, sehingga mempengaruhi penghasilan keluarga yang cenderung stabil jika dibandingkan kawasan nelayan. Penghasilan keluarga yang memadai akan menunjang pertumbuhan anak, karena orangtua dapat memenuhi semua kebutuhan primer maupun sekunder anak. Keluarga yang berpenghasilan tinggi akan memiliki kesempatan lebih besar untuk mendapatkan pelayanan umum yang lebih baik seperti pelayanan kesehatan, pendidikan, aksesbilitas jalan, dan sebagainya (Anisa 2012).

Pengeluaran kebutuhan keluarga per hari baik kawasan buruh industri dan kawasan nelayan sama-sama terjadi pengeluaran per hari yang tergolong rendah (Tabel 7). Pengeluaran pangan rumah tangga yang rendah menunjukkan daya akses ekonomi yang rendah pula (Purwanti 2014). Rendahnya pengeluaran di kedua kawasan dimungkinkan karena bertempat tinggal di Kota Surabaya sebagai kota metropolitan dengan biaya hidup yang tinggi, sehingga pengeluaran yang rendah pun terasa berat bagi keluarga yang tergolong memiliki tingkat status sosial ekonomi menengah dan bawah. Meskipun terkesan sulit terpenuhinya kebutuhan nutrisi dalam rumah tangga karena rendahnya pengeluaran per hari, namun jika orangtua tergolong berpendidikan tinggi dan lingkungan tempat tinggal yang mendukung kebutuhan nutrisi, maka hal tersebut tidak menjadi masalah. Tingginya tingkat pendidikan orangtua lebih mungkin untuk membuat keputusan dalam memenuhi gizi keluarga. Tempat tinggal seperti di kawasan nelayan juga mempengaruhi keluarga memiliki akses pangan dengan harga lebih terjangkau.

Berdasarkan status gizi IMT/U, tidak ditemukan perbedaan yang signifikan pada remaja laki-laki dan perempuan di kawasan buruh industri dan kawasan nelayan. Hal tersebut terlihat pada Tabel 2, hasil uji statistik chi square diperoleh nilai sebesar 0,305>0,05 pada kawasan buruh industri dan sebesar 0,656 > 0,05 pada kawasan nelayan. Dalam hal ini, indeks massa tubuh umumnya akan menyesuaikan dengan tinggi badan remaja baik yang tergolong stunting maupun tidak, kecuali jika memiliki permasalahan dengan indeks massa tubuh. Stunting hanya dapat ditentukan dengan membandingkan nilai z-score remaja dan nilai median dari angka baku rujukan WHO (2007). 
Tabel 5 menunjukkan adanya perbedaan yang signifikan kejadian stunting remaja lakilaki dan perempuan pada kedua sampel populasi dengan nilai sebesar 0,005 $<0,05$. Stunting pada remaja perempuan sebesar $42 \%$, sedangkan pada remaja laki-laki hanya sebesar $20 \%$. Adanya kasus stunting yang lebih banyak terjadi pada remaja perempuan menandakan bahwa remaja perempuan mengalami growth spurt yang lebih awal daripada remaja laki-laki. Sedikit kasus stunting pada remaja laki-laki diindikasikan proses growth spurt terjadi lebih lambat daripada remaja perempuan. Remaja perempuan dimungkinkan telah mengalami pubertas lebih awal daripada remaja laki-laki. Menurut Glinka SVD (2008), ketika remaja perempuan telah mengalami pematangan seksual, maka produksi estrogen akan menghentikan pertumbuhan; sebaliknya, ketika remaja laki-laki mengalami pubertas, maka produksi testosteron akan menaikkan growth spurt.

Ibu memiliki peran penting untuk menentukan status gizi anak. Diet ibu ketika hamil akan memberikan efek mendalam pada janin yang berujung pada kesehatan anak, dan efeknya bersifat transgenerasional (Jurmain, Kilgore \& Trevathan 2009: 301). Lebih lanjut, bila ibu kekurangan nutrisi selama kehamilan, sel telur yang berkembang pada janin perempuannya dapat rusak dan akan berdampak pada cucu-cucunya di masa depan. Kondisi tersebut bisa menjadi salah satu alasan banyaknya kasus stunting pada remaja perempuan daripada remaja laki-laki. Selain itu, sistem sosial patriarki diindikasikan masih berlaku pada kawasan buruh industri dan kawasan nelayan. Anak laki-laki akan memiliki kesempatan lebih baik dalam hal pemenuhan kebutuhan nutrisi selama masih dalam kandungan ataupun setelah dilahirkan, sehingga resiko stunting sedikit terjadi pada remaja laki-laki dan lebih banyak terjadi pada remaja perempuan.

Hasil penelitian ini membuktikan bahwa remaja pada usia 15-18 tahun baik yang berjenis kelamin laki-laki maupun perempuan masih ada yang mengalami stunting berdasarkan status gizi TB/U. Penelitian ini menjadi sangat penting dilakukan karena dapat dijadikan sinyal indikator pertumbuhan remaja akhir sebelum pada akhirnya akan berhenti untuk tumbuh. Pertumbuhan remaja perempuan akan berhenti pada sekitar usia 19 tahun dan remaja laki-laki akan berhenti pada sekitar usia 21-15 tahun (Bogin 1997 dalam Glinka SVD 2008: 3). Pada usia 15-18 tahun, remaja masih memiliki kesempatan untuk mengejar pertumbuhannya yang kurang dari tinggi badan normal, dengan cara memberikan asupan nutrisi yang baik sesuai dengan yang dibutuhkan oleh remaja. Oleh karena itu, ini bisa menjadi saran bagi pemerintah maupun pembaca bahwa untuk menanggulangi permasalahan stunting tidak hanya fokus pada ibu hamil atau balita, melainkan juga selama masa pertumbuhan anak hingga remaja. Agar efek yang ditimbulkan dari balita stunting di masa mendatang seperti kesulitan mencapai perkembangan fisik dan kognitif dapat diminimalisir dengan optimal.

\section{Simpulan}

Kejadian stunting ( $z$-score $<-2 \mathrm{SD}$ ) pada remaja laki-laki dan remaja perempuan lebih banyak terjadi di kawasan nelayan daripada di kawasan buruh industri. Lingkungan sosial ekonomi yang berbeda antara kedua kawasan dapat mempengaruhi pertumbuhan remaja. Faktor-faktor sosial ekonomi yang diukur dalam penelitian ini adalah pekerjaan orangtua, pendidikan orangtua, penghasilan keluarga per bulan, dan pengeluaran kebutuhan keluarga per hari. Remaja di kawasan nelayan lebih banyak berstatus sosial ekonomi bawah, sedangkan di kawasan buruh industri lebih banyak berstatus sosial ekonomi atas. 
Perbedaan status sosial ekonomi yang signifikan diindikasikan dapat mempengaruhi status pertumbuhan remaja yang dapat menyebabkan stunting.

Status gizi IMT/U remaja laki-laki dan remaja perempuan yang ada di kawasan buruh industri dan nelayan tidak menunjukkan perbedaan yang signifikan. Dalam hal ini, indeks massa tubuh umumnya akan menyesuaikan dengan tinggi badan remaja baik yang tergolong stunting maupun tidak, kecuali jika memiliki permasalahan dengan indeks massa tubuh. Stunting lebih banyak terjadi pada remaja perempuan daripada remaja lakilaki. Kebutuhan gizi ibu yang kurang selama kehamilan juga berdampak rusaknya sel telur pada janin perempuan dan berimbas pada cucu-cucunya di masa depan. Sistem sosial yang masih menganut patriarki mengindikasikan anak laki-laki memiliki kesempatan lebih baik dalam pemenuhan kebutuhan gizi selama masih dalam kandungan dan setelah dilahirkan.

\section{Daftar Pustaka}

Andriati R (2018) Buku Ajar Antropologi Maritim. Surabaya: Revka Petra Media.

Anisa P (2012) Faktor-Faktor yang Berhubungan dengan Kejadian Stunting pada Balita Usia 25-60 Bulan di Kelurahan Kalibaru Depok Tahun 2012. Skripsi, Universitas Indonesia, Depok.

Cameron N (2002) Human Growth, Curve, Canalization, and Catch-Up Growth. In Human Growth and Development. California: Elsevier Science, pp. 1-20.

Damayanti RA, Muniroh L \& Farapti (2016) Perbedaan Tingkat Kecukupan Zat Gizi dan Riwayat Pemberian ASI Eksklusif pada Balita Stunting dan Non-Stunting. Media Gizi Indonesia, 11(1): 61-69.

Glinka SVDJ (2008) Makna Perubahan Perilaku dan Proses Ontogenesis Sebagai Penjelasan Evolusi. Dalam: Manusia Makhluk Sosial Biologis, Myrtati Dyah Artaria (ed). Surabaya: Airlangga University Press.

Johnston FE (2002) Social and Economic Influences on Growth and Secular Trends. In Human Growth and Development. California: Elsevier Science, pp. 197-212.

Jurmain R, Kilgore L \& Trevathan W (2009) Essentials of Physical Anthropology Seventh Edition, USA: Wadsworth Cengage Learning.

Katzenberg MA \& Saunders SR (2008) Biological Anthropology of The Human Skeleton. New Jersey: WILEY-LISS.

Kementerian Kesehatan RI (2018) Buku Saku Pemantauan Status Gizi Tahun 2017. Jakarta: Kementerian Kesehatan RI.

Nasikhah R \& Margawati A (2012) Faktor Risiko Kejadian Stunting pada Balita Usia 2436 Bulan di Kecamatan Semarang Timur. Journal of Nutrition College, 1(1):176184.

Ngaisyah RD (2015) Hubungan Sosial Ekonomi dengan Kejadian Stunting pada Balita di 
Desa Kanirogo, Saptosari, Gunung Kidul. Jurnal Medika Respati, 10(4): 65-70.

Ni'mah K \& Nadhiroh SR (2015) Faktor yang Berhubungan dengan Kejadian Stunting pada Balita. Media Gizi Indonesia, 10(1): 13-19.

Permatasari DF \& Surmarmi S (2018) Perbedaan Panjang Badan Lahir, Riwayat Penyakit Infeksi, dan Perkembangan Balita Stunting dan Non Stunting. Jurnal Berkala Epidemologi, 6(2): 182-191.

Pradani DP, Rahayu MJ, \& Putri RA (2017) Klasifikasi Karakteristik Dampak Industri pada Kawasan Permukiman Terdampak Industri di Cemani Kabupaten Sukoharjo. Arsitektura, 15 (1): 215-220.

Pusat Data dan Informasi Kementerian Kesehatan RI (2018) Situasi Balita Pendek (Stunting) di Indonesia. In Situasi Balita Pendek (Stunting) di Indonesia. Jakarta: Pusat Data dan Informasi.

Ramadhan KF, Simanungkalit SF \& Wahyuningtyas W (2019) Faktor-Faktor yang Berhubungan dengan Kejadian Stunting pada Remaja di SMP Setia Negara Depok. Nutri-Sains, 3(1): 1-8.

Budiman AAS \& Anshariah (2018) Analisis Dampak Positif Industri terhadap Lingkungan Masyarakat. Jurnal Geomine, 6(2): 54-59.

Setyorini HB (2013) Budaya Kemiskinan Nelayan di Mangunharjo Semarang. Jurnal Sabda, 8: 7-17.

Sulastri D (2012) Faktor Determinan Kejadian Stunting pada Anak Usia Sekolah di Kecamatan Lubuk Kilangan Kota Padang. Majalah Kedokteran Andalas, 36(1): 3950 .

Purwanti TB (2014) Pendekatan Rawan Pangan dan Gizi: Besaran, Karakteristik, dan Penyebabnya. Forum Penelitian Agro Ekonomi, 32(1): 1-17.

Tim Nasional Percepatan Penanggulangan Kemiskinan (2017) 100 Kabupaten/Kota Prioritas Intervensi Anak Kerdil (Stunting), Jakarta: TNP2K.

Trihono, Atmarita, Tjandrarini DH, Irawati A, Utami NH, Tejayanti T \& Nurlinawati I (2015) Pendek (Stunting) di Indonesia, Masalah dan Solusinya, Jakarta: Lembaga Penerbit Balitbangkes.

Ulfani DH, Martianto D \& Baliwati YF (2011) Faktor-Faktor Sosial Ekonomi dan Kesehatan Masyarakat Kaitannya dengan Masalah Gizi Underweight, Stunted, dan Wasted di Indonesia: Pendekatan Ekologi Gizi. Journal of Nutrition and Food, 6(1): $59-65$.

World Health Organization (2007) Growth Reference Data for 5-19 Years. Geneva: WHO. 